\title{
UPTAKE OF NITROUS OXIDE BY MAN
}

\author{
Robert Virtue, Duane L. Sherrill and George D. Swanson
}

\section{ABSTRACT}

\begin{abstract}
Because of discrepancy in reports concerning the rate of uptake of nitrous oxide by man, it seemed desirable to measure this factor when automatic control of concentrations and rapid computer measurement of breath to breath uptake became available. Six subjects inhaled 25 per cent nitrous oxide for two hours. Total uptake and alveolar uptake were determined. The rotal inhaled uptake, adjusted for a $70 \mathrm{~kg}$ subject inhaling 75 per cent nitrous oxide, corresponded well with an absorption of about $1000 \mathrm{ml}$ the first minute. After a wash-in period of less than four minutes, the alveolar uptake, which at that time and subsequently equaled the total uptake, decreased approximately according to the square root of time in minutes. Considerable variation appeared between individuals, but each course approximated the same type of decrease. Absorption continued to occur during the two hour period of observation.
\end{abstract}

KeY Words: ANAESThetics, Gases, nitrous oxide, uptake.

\section{INTRODUCTION}

THE RATE OF uptake of nitrous oxide by man was measured in 1954 by Severinghaus, ${ }^{1}$ who found that it could be described by a factor closely correlated with the square root of time (time ${ }^{-12}$ ) in minutes. That is, if $\mathrm{X} \mathrm{ml}$ of nitrous oxide were taken up during the first minute of inhalation, then one-fifth of $\mathrm{X} \mathrm{ml}$ would be absorbed during the 25 th minute, and one-tenth of $\mathrm{X} \mathrm{ml}$ would be absorbed during the 100th minute, i.e, $\dot{\mathrm{V}}_{2} \mathrm{O}(\mathrm{t})$ $=\dot{\mathrm{V}}_{\mathrm{N}_{2} \mathrm{O}}\left(\mathrm{t}_{0}\right) / \sqrt{\mathrm{t}}$. Since that time, this concept has been applied satisfactorily to clinical practice. ${ }^{2,3}$ Some workers who have measured the uptake of nitrous oxide in closed anaesthetic systems have reported significant deviations from this notion, especially after a "steady state" had been obtained. For example, Barton and Nunn $^{4}$ found an absorption of $110-120 \mathrm{ml} / \mathrm{min}$ consistently after one hour of anaesthesia. Forbes ${ }^{5}$ found a steady uptake of nitrous oxide after 20 minutes of inhalation and calculated that less than $100 \mathrm{ml} / \mathrm{min}$ would be absorbed if the

Robert Virtue, M.D., Ph.D., Professor Emeritus of Anesthesiology; Duane L. Sherrill, B.S., Research Assistant; George D. Swanson, Ph.D., Associate Professor of Anesthesiology \& Biometrics, Director of Anesthesiology Research Laboratory; Department of Anesthesiology, University of Colorado Health Sciences Center, Denver, Colorado 80262.

This study was supported in part by Grant HL-22978 from the National Heart, Lung, and Blood Institute. subject inhaled between 50 and 75 per cent nitrous oxide. Lin, Mostert and Benson 6 believed that the original rapid uptake reflects chiefly "Functional Residual Capacity wash-in and not uptake by the blood-clearly demonstrating the near constant uptake of inhalation anaesthetics across the alveolar membrane."

A mass spectrometer has been developed ${ }^{7}$ which is capable of measuring volume as well as concentrations, so permitting instantaneous determination of breath-to-breath gas exchange. The growing general interest $t^{8,8 a}$ in closed circuits for administering anaesthetics accentuates the desirability of making a critical examination of the rate of uptake of nitrous oxide.

\section{METHOD}

After obtaining approval of the Human Research Committee and informed consent from the subjects, six volunteers inhaled 25 per cent nitrous oxide and 75 per cent oxygen for two hours. Gases were delivered from a conventional anaesthetic machine which had been properly calibrated. Inhalation and exhalation were through a mouthpiece which was directly attached to a mass spectrometer. A non-breathing system was used. The mass spectrometer was calibrated for volume and concentration of all gases used. A nosepiece prevented leaks, the absence of which was confirmed by the lack of nitrogen shown by the mass spectrometer.

Can. Anaesth. Soc. J., vol. 29, no. 5, September 1982 
Values determined by the mass spectrometer were recorded and correlated by a computer. They included volume of inhaled nitrous oxide and oxygen; volume of exhaled nitrous oxide, oxygen, and nitrogen; end-tidal concentrations of nitrous oxide, oxygen, and nitrogen; duration of each breath.

Quantities of nitrous oxide exchanged were determined by assessing alveolar uptake using a method described in another report. ${ }^{9}$ The method for measuring the quantity of nitrous oxide absorbed into the blood (alveolar uptake) involved computing the uptake at the mouth and subtracting the estimate of the nitrous oxide taken into the pulmonary stores. The total nitrogen exhaled after breathing nitrogen-free mixtures (estimate of Functional Reserve Capacity) was used with the measurement of the end-tidal nitrous oxide to compute the nitrous oxide volume in the pulmonary stores on a breath-to-breath basis.

\section{Results}

The absorption of nitrous oxide at the mouth of our subjects agreed well with the uptake as postulated by Lin et $\mathrm{al}^{10}$ and as measured by Severinghaus ${ }^{1}$ during the early phases of anaesthesia. It is necessary that the lung volumes be filled with the inhaled substance before the alveolar uptake can be equivalent to that at the mouth. Consequently, figure 1 shows a greater total early uptake of nitrous oxide than alveolar uptake. However, these two values became identical within four minutes of inhalation of nitrous oxide. The dotted line of figure 1 demonstrates what the uptake of nitrous oxide would be if the four minute figure was used as a basis for calculating the progressive decrease according to time ${ }^{-1 / 2}$. The dot and dash line represents the total uptake. The solid line shows average values found for the alveolar uptake of the six subjects, corrected to $70 \mathrm{~kg}$ weight each.

Figure 2 illustrates on a $\log \log$ graph individual actual absorption values of nitrous oxide compared to the amount (dotted line) which would be taken up calculating the average at four minutes and then decreasing with time ${ }^{-1 / 2}$.

The majority of the individual values were somewhat less than the line calculated using time $e^{-1 / 2}$ indicates; this is in accord with the data represented by figure 1 , which shows an average slightly lower than the calculated line. Note that the individual lines below the average generally remained consistently below, and the

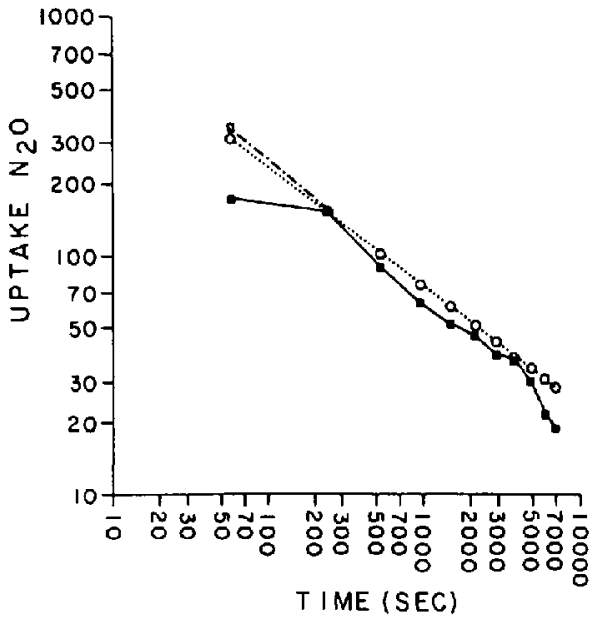

FIGURE 1 Uptake of nitrous oxide, average of six subjects. Numbers on $\mathrm{Y}$ axis represent $\mathrm{ml}$ of nitrous oxide. Dotted line is uptake of nitrous oxide calculated on basis of time ${ }^{-12}$, starting at the 4th minute when alveolar and total uptakes are equal, average of six subjects. Dashed and dotted line represents total uptake, average of six subjects. Solid line denotes alveolar uptake, six subjects. Alveolar and total uptakes are equivalent after four minutes.

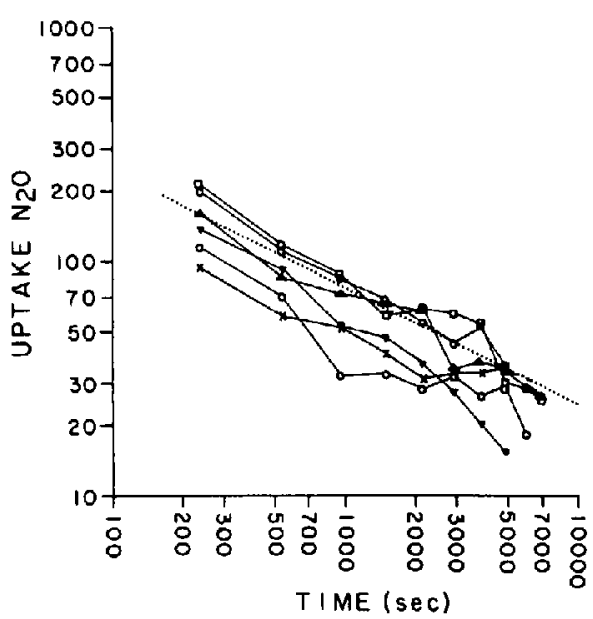

FIGURE 2. Absorption of nitrous oxide by individuals. Numbers on $\mathrm{Y}$ axis denote $\mathrm{ml}$ of nitrous oxide. Dotted line gives average uptake calculated as starting at the 4 th minute and continuing on the basis of time $^{-1 / 2}$. Triangles show uptake by a slender subject. Note rapid decrease as saturation approaches. $X$ denotes uptake by an obese subject. Note that uptake did not diminish after 2000 seconds (33 minutes) for the duration of the measurement. 
TABLE I

Average Uptake PER 70 Kg PER MINUTE OF SIX Subjects InHaling 25 Per Cent Nitrous OXide

\begin{tabular}{cccc}
\hline Minutes of & $\begin{array}{c}\text { Mean } \\
\text { Extake } \\
\text { ml }\end{array}$ & $\begin{array}{c}\text { Average } \\
\text { Deviation } \\
\text { from mean } \\
\text { ml }\end{array}$ & $\begin{array}{c}\text { Percent } \\
\text { Deviation } \\
\text { from mean }\end{array}$ \\
\hline 1 & 174 & 52 & 30 \\
4 & 153 & 38 & 25 \\
9 & 89 & 19 & 21 \\
16 & 63 & 18 & 29 \\
25 & 52 & 12 & 23 \\
36 & 46 & 18 & 39 \\
49 & 38 & 9 & 24 \\
64 & 37 & 10 & 27 \\
81 & 30 & 5 & 17 \\
100 & 22 & 8 & 37 \\
& & & AVG 27 \\
\hline
\end{tabular}

greater intakes were generally higher throughout the measurements. Table I shows the average variation from the mean value of nitrous oxide absorbed by the six individuals, presented at intervals which are squares of whole minutes. Muscular lean subjects absorbed less than average quantities of nitrous oxide, for saturation of their tissues was approached more rapidly, while an obese individual continued to absorb fairly large quantities because of relatively slower saturation.

Although it was diminishing, uptake was appreciable and was continuing at the end of the two hour period.

\section{Discussion}

On inhalation of a volatile substance, the volume of the first breath amounts to only a fraction of the lung volume. Consequently only a portion of the substance first entering the respiratory system reaches the alveoli. The same is true for the next succeeding breaths. Several inhalations are required before the lung stores are saturated with the inhalant. The alveolar uptake then, during the first moments cannot be as large as the total quantity taken into the pulmonary system. Lin and Mostert ${ }^{10}$ recognized this fact and stated that a large original uptake was needed to fill the functional reserve capacity of the lung. Our data bear out this fact.

Alveolar uptake and total uptake became identical within a few minutes, the actual time depending on ventilation and flow. In no case were more than four minutes required with our subjects. Absorption continued thereafter throughout the duration of the measurements, diminish- ing as the tissues became closer to saturation, which was not complete within two hours. Data from earlier measurements ${ }^{11}$ showed that absorption continues for at least three hours. Our data support a recent report ${ }^{12}$ (a calculation without experimental data) concerning alveolar gas which states "In practice, anaesthetic uptake will vary with time throughout the course of an anaesthetic, decreasing at a rapid rate early in administration and still changing at a slow rate after several hours of administration."

Saturation would occur more slowly in obese persons, which was shown precisely by our subjects.

The occurrence of continuing uptake is in contrast to the reports of those who believe that a steady state of nitrous oxide absorption occurs after saturation of the pulmonary stores. ${ }^{4-6}$ Observers who found a constant rate of nitrous oxide uptake after the first few minutes may not have had an entirely closed system, such as Barton and Nunn's ${ }^{4}$ withdrawal of gas for analysis; they may not have maintained concentrations of nitrous oxide and oxygen strictly in accord with the uptake by patients; the circuits may have been opened for suction; or they may not have had facilities for accurately measuring small quantities of gas.

The average first minute uptake of 25 per cent nitrous oxide by our subjects was $337 \mathrm{ml} / 70 \mathrm{~kg}$. If this figure is projected to a 75 per cent concentration, the value of $1011 \mathrm{ml} / \mathrm{min}$ is remarkably close to the $1000 \mathrm{ml}$ estimated by Severinghaus.' Uptake of nitrous oxide during and after the fourth minute coincided well with a rate calculated as diminishing with time $e^{-12}$. The total absorption by our subjects was slightly lower than this amount (see figure 1). Plotting data on a $\log \log$ scale affords two features: One, that a graph of uptake estimated on the basis of time $^{-1 / 2}$ will be a straight line; the other, that small differences are emphasized. In this report, relationships during the first few minutes are seen more easily, as are the continuing small uptakes between one and two hours.

Changes in absorption after the first hour were not large. To illustrate, with $1000 \mathrm{ml}$ absorbed the first minute, diminution with time ${ }^{-12}$ would mean that $100 \mathrm{ml}$ would be absorbed the 100 th minute and $91 \mathrm{ml}$ would be absorbed the $121 \mathrm{st}$ minute. Recognition of these small differences is difficult without special care. This explains why, in a ten litre system (vital capacity plus breathing bag, tubes and canister) workers can "coast" for 45 minutes ${ }^{13}$ using a closed system by turning 
off the nitrous oxide completely with little change in concentration of nitrous oxide.

A quantity of nitrous oxide is lost through skin, but this is small in comparison with the amount absorbed. Orcutt et $\mathrm{al}^{14}$ and also Stoelting et $\mathrm{al}^{15}$ measured that this loss amounted to 6 or $7 \mathrm{ml} / \mathrm{min}$ when the patients inhaled nitrous oxide. The loss rose from zero gradually and reached a plateau at some time between 60 and 100 minutes.

Figure 2 illustrates the individual uptake of nitrous oxide compared to the average decline (dotted line) based on uptake at four minutes and calculated according to time ${ }^{-1 / 2}$ basis for decline. Although the average deviation from the mean uptake (Table I) was 27 per cent, the subjects with uptakes above average remained generally high throughout, and vice versa.

Realization that fairly large individual differences occur should alert the anaesthetist to look for and to recognize each patient's reaction to drugs that are given, rather than relying simply on calculated average values.

\section{REFERENCES}

1. Severinghaus, J.W. The rate of uptake of nitrous oxide in man. J. Clin. Invest. 33: 1183-1189 (1954)

2. Weingarten, J. Clinical application of low flow, closed circuit and circuit injection techniques. pp. 67-74 in Low Flow and Closed System Anesthesia, Eds. Aldrete, J.A., Lowe, J.H. and Virtue, R.W. Grune \& Stratton, New York, 1979.

3. Lowe, H.J. \& ERNST, E.A. The quantitative practice of anesthesia. Williams and Wilkins, Baltimore, 1981. Chap. 5, pp. 67-97.

4. BARTON, F, \& NunN, J.F. Totally closed circuit nitrous oxide/oxygen anesthesia. Br. J. of Anaesth. 47: 350-357 (1975)

5. Forbes, A.R. Inspired oxygen concentrations in semiclosed circle absorber circuits with low flows of nitrous oxide and oxygen. Br. J. Anaesth. 44 1081-1084 (1972).

6. LiN, C.Y., Mostert, J.W. \& Benson, D.W. Closed circuit system: a new direction in the practice of anesthesia. Acta. Anaesth. Scand. 24: 354-361 (1980).

7. Sodal, I.F. \& Swanson, G.D. Mass Spectrometry: Current technology and implications for anesthesia, in Low Flow and Closed System Anesthesia, Eds. Aldrete, J.A., Lowe, J.H. and Virtue, R.W. p. 167-182, Grune \& Stratton, New York, 1979.

8. Low Flow and Closed System Anesthesia. Eds. Aldrete, J.A., Lowe, J.H. and Virtue, R.W. Grune and Stratton, New York, 1979.

8a. Jordan, M.J. \& BushmaN, J.A. Closed-circuit halothane and enflurane using an in-circle Goldman vaporizer. Br. J. Anaesth. 53: 1285 (1981).

9. Swanson, G.D. Breath-to-breath considerations for gas exchange kinetics. Exercise bioenergetics and gas exchange. p. 211-222, 1980. Elsevier' North Holland Biomed. Press, Amsterdam.

10. LIN, C.Y. \& MosterT, J.W. Inspired oxygen and nitrous oxide concentrations in essentially closed circuits. Anaesthetist. 26: 514-517 (1977).

11. VIRtue, R.W. Minimal flow nitrous oxide anesthesia. Anesthesiology, 40: 196-198 (1974).

12. CONWAY, C.M. Alveolar gas relationships during use of the circle system with carbon dioxide absorption. Br. J. Anaesth. 53: 1135 (1981).

13. GorsKy, B.H., Hall, R.L. \& Redord, J.E. A compromise for closed system anesthesia. Anesth/Analg. 57: 18-24 (1978)

14. ORCutT, F.S. \& WaTERS, R.M. The diffusion of nitrous oxide, ethylene and carbon dioxide during anesthesia: Including a new method for estimating nitrous oxide in low concentrations. Anesth. Analg. 12: 45 (1933).

15. Stoelting, R.K. \& Eger, E.I. Percutaneous loss of nitrous oxide, cyclopropane, ether and halothane in man. Anesthesiology 30: 278 (1969).

\section{RESUMÉ}

C'est en constatant la discordance entre les résultats des études de mesure de la captation du protoxyde d'azote chez l'homme qu'il est apparu désirable de reprender ces mesures de façon plus précise en utilisant le contrôle automatique des concentration avec la mesure rapide de la captation par cycle respiratoire. On a fait inhaler du protoxyde d'azote à 25 pour cent à six sujets. Les captations totale et alvéolaire ont été mesurées. La captation inhalée totale ajustée pour un sujet de $70 \mathrm{~kg}$ inspirant une concentration de protoxyde d'azote à 75 pour cent correspondait bien avec une absorption de $1000 \mathrm{ml}$ à la première minute. Après une période de moins de quatre minutes, la captation alvéolaire qui à ce moment et subséquemment égalait la captation totale, a diminué à une vitesse se rapprochant la racine carrée du temps en minute. Les variations individuelles ont été considérables mais la forme de la courbe de déclin était à peu prés identique chez tous les sujets. L'absorption s'est continuée pendant la période de deux heures. 